REGULAR ARTICLE

\title{
FARMERS' CHOICE OF ADAPTATION STRATEGIES TO CLIMATE CHANGE AND VARIABILITY IN ARID REGION OF GHANA
}

\author{
Hamdiyah ALHASSAN ${ }^{1}$, Paul Adjei KWAKWA ${ }^{2}$, William ADZAWLA ${ }^{* 1,3}$
}

\author{
Address: \\ ${ }^{1}$ University for Development Studies, Department of Agricultural and Resource Economics, Tamale, Ghana. \\ ${ }^{2}$ Presbyterian University College Ghana, Department of Business Economics, Akuapem Campus, Akropong-Akuapem, \\ Eastern Region, Ghana. \\ ${ }^{3}$ University of Cheikh Anta Diop, West African Science Service Centre on Climate Change and Adapted Land Use \\ (WASCAL), Climate Change Economics, BP 5683, Dakar, Senegal \\ * Corresponding Author's email: adzawla.w@edu.wascal.org
}

\begin{abstract}
This study used multinomial logit regression to determine the factors that influence farmers' choice of adaptation strategies to climate change and variability of farmers in Savelugu-Nanton district, Northern region of Ghana. A simple random sampling was used to select 180 farmers. The data was analysed using a Multinomial logit regression model. From the results, the level of climate change and variability awareness was high and the adaptation strategies identified were mixed cropping, change crop varieties, changing planting time/date, soil conservation techniques, increased irrigation, increased female livestock herd, and seasonal migration. Farmers confirmed empirically observations that climate change would lead to a reduction in crop production. Also, gender, age, education, household size, farming experience, access to extension, access to credit, access to mobile phone and perceived decreased rainfall influenced farmers' choices of a particular adaptation strategy. The findings support and justified calls for education of farmers on climate change and variability.
\end{abstract}

Keywords: Adaptation; Climate change and variability; Multinomial Logit Regression model; Perception JEL: C31, C35, N50, O13, Q12

\section{INTRODUCTION}

In recent decades, climate change and variability $(\mathrm{CCV})$ is one of the most topical issues. This is particularly due to the effects it has on other developmental challenges such as food security and poverty as well as its effect on a stable environment for future generations. Its effect on sustainable development is negative and manifested in all sectors of the economy. Generally, the conclusions from climate literature suggests a 'changing climate'. However, the trends, impacts and response thereof are not universally distributed. One of the most vulnerable locations is the Africa continent (Arslan et al., 2015; Nyasimi et al., 2014), where Ghana is located. This is largely due to the fragility of African economies and their low adaptive capacities.

Climate model projections show that rainfall patterns would become more erratic and unpredictable than currently observed (Serdeczny et al., 2016; Laube et al., 2012) while temperatures would rise. Over the $20^{\text {th }}$ century, precipitation decreased by $3 \%$ in the subtropical areas (Uddin $\boldsymbol{e t} \boldsymbol{a l}$. , 2014). Expectedly, the effects on all sector, especially, the agriculture sector gained documentation in recent times. Ghana's climatic conditions have changed in the past four decades and this phenomenon is expected to continue in the future (Stanturf et al., 2011). Already, the country is experiencing increasing temperatures and erratic rainfall patterns. Unfortunately, among the various sectors, agriculture sector, especially in the African region, is most vulnerable. This is due to the high dependence of the sector on natural resources (Nhemachena and Hassan, 2007) and the low adoption of modern technologies (Jones and Thornton, 2003; Kurukulasuriya and Rosenthal, 2003). However, Africa's vulnerability to climate change is complex (Nyasimi et al., 2014). Estimates show that crop yields in the continent is likely to see as high as $50 \%$ reduction by 2050 due to climate change (Jones and Thornton, 2003). The undernourishment in sub-Saharan Africa would increase by $25-90 \%$ by 2050 if warming increase between 1.2 $1.7^{\circ} \mathrm{C}$ (Lloyd et al., 2011).

Responding to $\mathrm{CCV}$ requires mitigation and/or adaptation. While the former is generally long-term strategy, the latter are short-term and localized measures to offset the impacts of CCV. As simply put, societies must adapt to ensure survival of lives (Arku, 2013). Adaptations, which is the focus of this study is defined as the interventions carried out to improve society's capacity to adjust to $\mathrm{CCV}$, reduce the negative effect or take advantage of the opportunities offered by a changing climate. Adaptation to climate change is of two types; autonomous and planned adaptation. Autonomous adaptation is a short-run micro-analysis of farmer decision in response to seasonal climatic variations, economic and other factors whiles planned adaptation is the long-run macro-analysis at national or regional levels focusing on the long-term climatic changes, market and other factors 
(Bradshaw et al., 2004). The study however focused on autonomous adaptation.

Farmers under various conditions adopts various adaptation strategies, primarily, to increase or at least, maintain crop yields. CCV cannot be sufficiently addressed if effective adaptation strategies are not adopted (Nyasimi et al., 2014). With further pressure on agricultural livelihoods, farmers further adopt various coping and adaptation strategies (Laube $\boldsymbol{e t}$ al., 2012) in order to maintain their livelihoods. For instance, unlike previous decades where irrigation facilities are solely provided by the government, farmers have recently engaged in farmer-driven irrigation farming to provide food for their families. As has been the case globally, farmers in Ghana have engaged in a number of innovative strategies due to diverse economic and environmental challenges. This notwithstanding, (Phillipo et al., 2015) noted that knowledge on adaptation to $\mathrm{CCV}$ in subSaharan Africa is dotted due to the absence of comprehensive adaptation framework. This is not surprising as several adaptation strategies including crop diversification, mixed cropping, mixed crop-livestock farming systems, irrigation, using drought resistant varieties, high-yield water sensitive crops, migration, changing planting and harvesting dates, and modifying the length of the growing period were adopted and reported in the literature (Nzeadibe et al., 2011; Enete et al., 2011; Codjoe and Owusu, 2011; Hassan and Nhemachena, 2008; Quaye, 2008).

Scholarly review of farmers' adaptation to CCV has gained prominence. Therefore, a stock of current literature is important to give focus of this present study. From the literature, knowledge on climate change have a major implication on adaptation. Farming households that are able to predict the trend of the climatic conditions correctly may be able to select responsive adaptation strategies. Similarly, the choice of adaptation strategy depends on the soil properties, location and climatic conditions of an area (Uddin et al., 2014). Besides technological revolution, local practice (the various activities implemented by farmers) is important in the success of $\mathrm{CCV}$ adaptation. Empirical estimations revealed a number of factors that influence $\mathrm{CCV}$ adaptation or adaptation intensity (Mabe et al., 2014; Uddin et al., 2014).

The role of agriculture in Ghana's economy is inevitable. It provides food and income for majority of the population (Al-hassan, 2007), employs most of the populace and also contributes greatly to the foreign exchange earnings in the country. However, farming in the country is dominated by small-scale farmers with very low productivity that is attributable to outmoded farming techniques; soil degradation caused by overgrazing and deforestation; poor agricultural and financial services and frequent floods and droughts. The high reliance of Ghana's economy on agriculture called for sustainable adaptation to $\mathrm{CCV}$. This must involve the adoption of most effective, efficient and localized adaptation strategies. Due to its geographical location and low adaptive capacities, the northern parts of Ghana is more vulnerable to CCV. Agriculture is also a pronounced economic activity in the north than in the south. These conditions mean that deliberate efforts, at least through research must be conducted in these areas to provide periodic evidence-based recommendations to policy makers. Therefore, although there is vast literature on CCV adaptation, the case of farming household in the northern parts of Ghana requires a further review. In addition, conflicting results exist particularly when it comes to the determining factors of adaptation. Some of the factors identified by past researchers are famers' socioeconomic characteristics, farm characteristics and farm management practices (Nzeadibe et al., 2011; Hassan and Nhemachena, 2008). It is therefore impossible to apply recommendations from these studies to farming households in the study area without a restriction. This study addresses these limitations by identifying the CCV adaptation strategies in the Municipality and the factors responsible for their adoption. The aim is to provide policy recommendations that would enhance farmers' adaptation to $\mathrm{CCV}$ and ensure that the impacts from $\mathrm{CCV}$ are reduced.

\section{DATA AND METHODS}

\section{Theoretical framework}

The theory behind this study is the utility maximization theory. The theory suggests that economic agents (farmers) are rational and if faced with the decision to choose among two or more CCV adaptation strategies, they will prefer the option that gives the highest utility or net benefit. In this study, farmers are assumed to maximize their utility or net benefits if they adopt a particular strategy. Hence, the probability that an adaptation strategy is chosen depends on the expected utility from that adaptation strategy. Assume that farmer $i$ 's utility from adopting adaptation strategy $j$ is given as in Eq. 1.

$U_{i j}=V_{i j}+\varepsilon_{i j}$

Where: $U_{i j}$ is farmer $i$ 's utility of choosing alternative $j$, $V_{i j}$ is the deterministic component of utility and $\varepsilon_{i j}$ is a stochastic element that represents unobservable influences on the farmer's choice. Using utility functions for two alternatives from (Eq. 1), the probabilities of a farmer choosing, say alternative $j$ or $k$ are in Eq. 2.

$P_{i j}=P\left(\varepsilon_{i j}-\varepsilon_{i k}<V_{i k}-V_{i j}\right)$
$P_{i k}=P\left(\varepsilon_{i k}-\varepsilon_{i j}<V_{i j}-V_{i k}\right)$

The probability that any particular respondent prefers option $j$ in the choice set to any alternative option $k$, can be expressed as the probability that the utility associated with option $j$ exceeds that associated with the other options (Eq. 3).

$P_{i j}=P\left\{V_{i j}+\varepsilon_{i j}>V_{i k}+\varepsilon_{i k} \nabla k \in C\right\}$

Where: $C$ is the set of all possible alternatives. In order to derive an explicit expression for these probabilities, an assumption is made about the distribution of the error terms. Assuming that error terms are independently 
Gumbel distributed the probability of choosing alternative $j$ can be expressed as Eq. 4 .

$P_{i j}=\frac{e^{X_{i j} \beta_{j}}}{\sum_{K=1}^{J} e^{X_{i k} \beta_{k}}}$

Equation 4 is known as the Multinomial logit model (MNL) which gives the probability that farmer $i$ will choose adaptation strategy $j$ among $C$ alternatives (McFadden, 1973), $\beta_{j}$ are the vector coefficients yet to be estimated and $X_{i j}$ denotes vector of explanatory variables which represents farmers' socio-economic characteristics, farm characteristics and perception of CCV. An important implication of this specification that follows from the independence of the error terms across the different options contained in the choice set is the property of the independence of irrelevant alternatives. This property requires that the probability of an option being chosen should be unaffected by the inclusion or omission of other alternatives (Hausman and McFaden, 1984).

Taking the differential of equation (4) with respect to the explanatory variables gives the marginal effects of the explanatory variables, which measures the expected change in probability of a particular option chosen with respect to a unit change in an explanatory variable from the mean (Greene, 2012). The marginal effects equation is presented as:

$\frac{d P_{j}}{d P_{k}}=P_{j}\left(\beta_{j k}-\sum_{j=1}^{J-1} P_{j} \beta_{j k}\right)$

\section{Empirical Model}

The MNL is used to analyse the determinants of farmers' decision to adopt a particular adaptation strategy in Ghana. This model is commonly used in adoption decision studies involving multiple choices (Hassan and Nhemachena, 2008). The MNL has advantages over binary probit or logit because it allows the analysis of decisions across more than two categories, correct for self-selection and interactions between different categories and also simple to compute (Tse, 1987). The estimated empirical model is expressed as:

$Y_{i}=\beta_{0}+\beta_{1}$ age $+\beta_{2} e d u+\beta_{3}$ gender + $\beta_{4}$ farmsize $+\beta_{5}$ hhsize $+\beta_{6}$ mar $+\beta_{7}$ farmexp + $\beta_{8}$ amobile $+\beta_{9}$ aext $+\beta_{10}$ acredit $+\beta_{11}$ Prain + $\beta_{12}$ Ptemp $+\varepsilon_{i}$

The dependent variable in the empirical model is the choice of an adaptation option from the set of adaptation strategies. These are soil and water conservation, changing crop varieties, increased irrigation, changing planting date/time as well as engaging in mixed cropping. The choice of the explanatory variables (Table 1) is based on data accessibility and literature.

\section{The Study Area}

The study was carried out in the Savelugu-Nanton district which has Savelugu as its capital town. With a population of 139,283 and a land area of 1790.7 square $\mathrm{km}$, the population density is about 61 person per sq. $\mathrm{km}$. There are
149 communities in the district of which 143 are rural, and approximately $80 \%$ of the populace resides in rural communities and $20 \%$ in the few urban towns. SaveluguNanton district is predominantly agrarian with about $97 \%$ of the district's economically active population (1854 years) involved in farming of staple food crops. The major crops include maize, rice, yam, groundnut, cowpea and soybean. Agricultural practices are mainly dependent on rainfall which is erratic resulting in seasonal unemployment.

Table 1: Description, Measurement and A priori Expectations of Explanatory variables.

\begin{tabular}{|c|c|c|c|}
\hline Variables & Description & Measurement & $\begin{array}{l}\text { A } \\
\text { priori }\end{array}$ \\
\hline Gender & Gender of farmer & $\begin{array}{l}1 \text { if male, } 0 \\
\text { otherwise }\end{array}$ & $-/+$ \\
\hline Age & Age & Years & - \\
\hline Mar & Marital status & $\begin{array}{l}1 \text { if married, } 0 \\
\text { otherwise }\end{array}$ & $-/+$ \\
\hline Edu & Educational level & $\begin{array}{l}1 \text { if formal } \\
\text { education, } 0 \\
\text { otherwise }\end{array}$ & + \\
\hline Farmexp & $\begin{array}{l}\text { Farming } \\
\text { experience }\end{array}$ & $\begin{array}{l}\text { Number of years } \\
\text { of farming }\end{array}$ & + \\
\hline $\begin{array}{l}\text { Farm } \\
\text { size }\end{array}$ & Farm size & Acres & + \\
\hline Hhsize & Household size & $\begin{array}{l}\text { Number of } \\
\text { household } \\
\text { members }\end{array}$ & $-/+$ \\
\hline Acredit & Access to credit & $\begin{array}{l}1 \text { if access, } 0 \\
\text { otherwise }\end{array}$ & + \\
\hline Aext & $\begin{array}{l}\text { Access to } \\
\text { extension }\end{array}$ & $\begin{array}{l}1 \text { if access, } 0 \\
\text { otherwise }\end{array}$ & + \\
\hline Amobile & $\begin{array}{l}\text { Mobile phone } \\
\text { access (owning a } \\
\text { phone) }\end{array}$ & $\begin{array}{l}1 \text { if access, } 0 \\
\text { otherwise }\end{array}$ & + \\
\hline Ptemp & $\begin{array}{l}\text { Perceived } \\
\text { increased } \\
\text { temperature }\end{array}$ & $\begin{array}{l}1 \text { if increased, } 0 \\
\text { otherwise }\end{array}$ & + \\
\hline Prain & $\begin{array}{l}\text { Perceived } \\
\text { decreased in } \\
\text { rainfall }\end{array}$ & $\begin{array}{l}1 \text { if decreased, } 0 \\
\text { otherwise }\end{array}$ & + \\
\hline
\end{tabular}

\section{Sampling, Data collection and Analysis}

Savelugu Nanton district was purposively selected because most of the communities' major sources of livelihoods are highly climate dependent which makes them highly vulnerable to the negative impacts of CCV. Already, there are signs of CCV in the Municipality. Two communities Libga and Zoggu were randomly selected and with the help of the District extension officers, lists of small holder farmers in the communities were obtained. From the list 180 small holder farmers were randomly sampled and data was obtained through semi- structured questionnaires. The information gathered include farmers' socio-economic and demographic features, farm characteristics, farmers' perceptions of changes in temperature and rainfall, and self-reported CCV adaptation strategies. Two focus group discussions were conducted to collect qualitative information on perceptions and experiences of 10 farmers (six males and four female farmers) from each community. Qualitative data were recorded, transcribed and analysed using 
content analysis to bring out various themes. The quanti tative data were analysed using Stata 14.

\section{RESULTS AND DISCUSSION}

\section{Socio-economic characteristics of respondents}

The survey (as shown in Table 2) in the study area covered $65 \%$ male farmer respondents and $35 \%$ female farmers. Majority of the respondents $(65 \%)$ are married while $35 \%$ are single. The mean age of the respondents is 33.8 years with youngest and oldest farmer having ages 17 years and 67 years, respectively. The educational level of the respondents is low as only $37.2 \%$ have some level of formal education. Approximately, there are 7 people in each sampled household. The mean farming experience is 19.42years, with the least and maximum being 2 years and 50 years respectively. The high experience in farming by the farmers means that the farmers can be able to notice any variation in the environmental conditions and act timely. Averagely, a farmer cultivated 6.52 acres of land. More than half $(54.9 \%)$ of the farmers received Agricultural extension services through contact. Also $61.7 \%$ and $79.7 \%$ of the farmers have access to credit facilities and mobile phone, respectively.

Table 2: Socio-economic characteristics of the respondents

\begin{tabular}{lrr}
\hline Variables & Frequency & Percentage \\
\hline Gender & & \\
Male & 117 & 65 \\
Female & 63 & 35 \\
Total & 180 & 100 \\
Educational level & & \\
Formal education & 67 & 37.2 \\
No formal education & 113 & 62.8 \\
Total & 180 & 100 \\
Marital status & & \\
Married & 117 & 65 \\
Not married & 63 & 35 \\
Total & 180 & 100 \\
\hline
\end{tabular}

\section{Farmers' awareness of $C C V$ in the area}

$\mathrm{CCV}$ awareness and knowledge is key in facilitating adoption of strategies that could be efficient under than socioeconomic conditions. It also influences the decision and rate at which smallholder farmers adopt modern and improved technologies available to minimize the harmful effect of CCV. Therefore, understanding farmers' knowledge on CCV have become the first step in adaptation studies. The implication drawn from previous studies is that adaptation to CCV is high if farmer's knowledge/awareness on changes of temperature and rainfall is high. To get information on their perceptions to $\mathrm{CCV}$, farmers were asked two sets of questions. Firstly, farmers were asked if they knew about CCV and secondly, if they have observed any change in rainfall intensity or temperature over the past ten years. The result is presented in Table 3.

The result shows that most of the farmers interviewed $(83.9 \%)$ were aware or knew of CCV. Of this group of farmers, as high as $82.8 \%$ of them had observed increasing temperature over the past 10 years, against $7.2 \%$ observed decreasing temperature and $10 \%$ had not observed any change in temperature over the past 10 years. With respect to changes in rainfall, majority $(85.7 \%)$ had observed decreasing rainfall whilst $14.3 \%$ reported that the intensity of the rains is increasing over the past 10 years. These individual farmer's perceptions were confirmed through focus group discussion. Below are some extracts from the focus group discussion:

"For the past 10 years access to water for irrigation is limited because the quantities of rain have reduced, most of our dugouts have dried up and are not able to provide us with water until the rainy season begins".

"Now we [can] sleep outside in the month of JuneJuly because our room is warm, but that was not the case in the past. In the past around this period the weather was too cold that, we have to sleep in our rooms".

This shows that the people are adjusting the living conditions in line with their observed changes in the climatic conditions. The high perception of farmers on CCV have been observed in earlier empirical studies (Limantol et al., 2016; Tadesse, 2009; Uddin et al., 2014; Mertz et al., 2009).

Perceived Effects of changes in temperature and rainfall In addition to understanding farmers' perceptions on $\mathrm{CCV}$, perceptions on the effects of these observed changes is vital. In Table 4, the result of farmers' perception on these effects is provided. Firstly, changes in temperature and rainfall has led to poor crop production $(33.3 \%)$. This confirms reports that $\mathrm{CCV}$ would have a negative effect on food production, for that matter, food security (Barimah et al., 2018). Farmer's dependence on rain-fed agriculture and natural resources as a sole source of livelihood is threatened by the variations in climatic conditions that directly affects agricultural productivity.

The second effect reported was water scarcity due to reduction in the quantity of rainfall $(21.7 \%)$. On their part, not only is low rainfalls affecting crop production but also, water availability for domestic purposes during some months in the harmattan season. This supports claims that climate change and population growth are mainly responsible for water scarcity and limiting irrigation potentials (Turner et al., 2011). A participant in the focus group discussion noted:

"Most of the dugouts have dried up, making it difficult for livestock to get water to drink and farmers to get water for irrigation."

About $18.6 \%$ reported increase in soil erosion/declining soil fertility. Soil infertility occurs when the mining of soil nutrients exceeds their replenishment, resulting in a negative balance of nutrients. With $\mathrm{CCV}$, high temperature can contribute to low soil productivity as it tends to reduce water in the soil. Consequently, this affects nutrient mineralization and their availability to crops (Rowell, 1995)

The tendency of prevalence of resilient pests and diseases was reported by $12.4 \%$ of the farmers. Thus, with increasing temperature and decreasing rainfalls, not would the pests and diseases increase, but they would be more resistant to existing control measures. Climate change has the ability to change the incidence of existing vector-borne 
diseases in humans and crops (FAO, 2007) and also affect the populations of insects and other vectors (Le ma and Majule, 2009). The effects on pests and diseases is also report during focus group discussion:

"The livestock have been getting strange diseases and most usually die from these diseases".

Other effects include poor livestock production $(8.30 \%)$ and increased suffering and poverty $(5.7 \%)$. Consistently, (Gandure and Alam, 2006) reported that $\mathrm{CCV}$ has the tendency of impoverishing rural farmers. Also noted by a participant in focus group discussion is: "Due to erratic rainfall and high temperature our crop yield is low, reducing our income and this has increased our sufferings".

Farmers' adaptive strategy to climate change and variability $(\mathrm{CCV})$

One of the aims of the study is to explore the various adaptation strategies used by farmers in response to CCV. The farmers have responded to changes in rainfall and temperature by adopting mixed cropping, changing planting date, increased irrigation, seasonal migrating to urban areas, changing crop variety, increasing female livestock and soil conservation techniques. They were however some who did nothing or did not adapt to the changing climatic conditions.

Mixed cropping involves the growing of two or more crops in proximity in the same field (Lema and Majule, 2009). This have the potential to curtail complete crop failure as different crops are affected differently by climate. For a staple crop, such as maize, instead of planting local varieties, farmers have opted to combine both local and improved varieties while some have completely shifted from local varieties to early maturing improved varieties. Since the onset of the rains have changed, farmers also do not plant their crops in the same periods as decades back. As a risk sharing measure, other farmers reported keeping female dominated herds to sustain and supplement their income. Relatedly, participants in focus group discussion noted:

"When crop fails due to unreliability of rain, and an alternative means of generating income is not possible, I sell my livestock to feed the family and buy farm inputs for the next season".

"To increase or maintain the number of livestock, I always sell the male animal and keep the females for reproduction. I do this to sustain my income in case the rain fails"

Seasonal migration, especially, by the youths is a major adaptation strate gy to CCV. People either locate to farming areas where the soils are relatively fertile and the rains are regular for farming activities or move to the urban and peri-urban areas for non-agricultural jobs.

Mostly, young people from the north migrate to southern Ghana during the dry season after harvesting and return in the rainy season to resume with their farming activities. Others may not return for farming but send remittances to reduce economic difficulties of their families.

Quoted from focus group discussion is:

"My children have to travel to Kumasi for Kayaye [head porting] during the dry season and return during the planting and harvest period to help with planting and harvesting",

".... I have to go to Kumasi to help in my senior brother['s] business and earn some income, which I use to feed my family".

However, farmers who failed to adapt also have their reasons. This includes insufficient credit facility, high cost of labour, high cost of irrigation and lack of ready market; all related to financial constraints. In their words:

"I do not have enough fund to buy pump for irrigation, it is expensive"; "it is expensive to pay labourers to worked on my farm"; and "farm inputs like fertilizer, improved crop varieties etc. are expensive nowadays"

"because we are farmers, banks don't want to give us loan, its difficult accessing credit as a farmer"

The fact that financial matters dominate is an indication that adapting to climate change is expensive and the lack of sufficient financial resources will prevent farmers from purchasing the necessary inputs and equipment needed to adapt. Consistently, Enete $\boldsymbol{e t}$ al. (2011) reported inadequate funding as a major challenge to adaptation to $\mathrm{CCV}$.

Table 3: Farmers awareness and Perceived Changes in temperature and rainfall

\begin{tabular}{lrr}
\hline Perception on CCV & Frequency & Percentage \\
\hline Perceived & 151 & 83.9 \\
Not perceived & 29 & 16.1 \\
Total & 180 & 100 \\
Perceived changes in temperature & & \\
Increased temperature & 125 & 82.8 \\
Decreased temperature & 11 & 7.2 \\
No changes in temperature & 15 & 10 \\
Total & 151 & 100 \\
Perceived changes in Rainfall & & \\
Increased rainfall & 22 & 14.3 \\
Decreased rainfall & 129 & 85.7 \\
No changes in rainfall & 0 & 0 \\
Total & 151 & 100 \\
\hline
\end{tabular}




\section{Adoption of climate adaptation strategies by farmers}

Table 4 shows the percentage distribution of the adoption of climate adaptation strategies by the farmers. At the focus group discussion, farmers listed eight adaptation strategies that they have adopted to reduce the negative effect of CCV. Out of these, six (mixed cropping, change of crop variety, changing planting time/date, adoption of soil conservation techniques, increased irrigation and no adaptation) farm management practices were identified as most important by the farmers. These are also outlined as prominent adaptation strategies in the literature (Codjoe and Owusu, 2011; Phillipo et al., 2015; Hassan and Nhemachena, 2008; Quaye, 2008). From Table 5, about $11.67 \%$ adapt none of the six strategies, $11.12 \%$ used soil conservation techniques, $15 \%$ changed crop varieties, $16.11 \%$ engaged in irrigated farming, $20 \%$ change planting date while $26.11 \%$ mixed cropping.

\section{Determinants of farmers' choice of adaptation strategy} to climate change and variability

The results of the estimates of the marginal effects along with the levels of statistical significance from the MNL are presented in Table 6. The dependent variable in the empirical model for this study is the choice of adaptation option from the set of adaptation strategies (Table 5) and the reference group assumed is the zero adaptors. From the result, a number of factors had significant effect on the

various climate adaptation strategies and this is discussed in the subsequent sections.

Table 4: Perceived Effects of Changes in temperature and rainfall on farmers*

\begin{tabular}{lr}
\hline Perceived effects of changes & Percentage \\
in temperature and rainfall & \\
\hline Poor crop production & 33.3 \\
Water scarcity & 21.7 \\
Soil erosion/declining soil fertility & 18.6 \\
Increased pest and disease & 12.4 \\
Poor livestock production & 8.3 \\
Increased suffering and poverty & 5.7 \\
Total & 100 \\
\hline
\end{tabular}

Note: Perceived effect reported by 151 respondents who had perceived changes in temperature and rainfall.

Table 5: Adaptation strategies used in the MNL model

\begin{tabular}{lr}
\hline Adaptation Strategies & Percentage \\
\hline No adaptation & 11.67 \\
Soil Conservation techniques & 11.12 \\
Changing crop varieties & 15.00 \\
Increased Irrigation & 16.11 \\
Changing planting date/ time & 20 \\
Mixed cropping & 26.10 \\
Total & 100 \\
\hline
\end{tabular}

Table 6: The Marginal effect of MNL Estimation

\begin{tabular}{|c|c|c|c|c|c|}
\hline $\begin{array}{l}\text { Explanatory } \\
\text { Variables }\end{array}$ & Soil conservation & $\begin{array}{l}\text { Changing crop } \\
\text { varieties }\end{array}$ & $\begin{array}{l}\text { Increased } \\
\text { Irrigation }\end{array}$ & $\begin{array}{l}\text { Changing planting } \\
\text { date/time }\end{array}$ & Mixed cropping \\
\hline \multirow[t]{2}{*}{ Age } & $-0.0037 *$ & $-0.044^{*}$ & 0.0538 & 0.01548 & -0.0549 \\
\hline & $(0.0940)$ & $(0.0944)$ & $(0.169)$ & $(0.2169)$ & $(0.318)$ \\
\hline \multirow[t]{2}{*}{ Gender } & -0.03494 & -0.1465 & 0.0065 & $-0.04106^{* *}$ & -0.05408 \\
\hline & $(0.206)$ & $(0.2077)$ & $(0.2270)$ & $(0.0356)$ & $(0.384)$ \\
\hline \multirow[t]{2}{*}{ Education } & -0.006475 & $0.01287 * *$ & 0.02494 & 0.1382 & 0.00429 \\
\hline & $(0.166)$ & $(0.026)$ & $(0.685)$ & $(0.872)$ & $(0.687)$ \\
\hline \multirow[t]{2}{*}{ Marital status } & -0.02035 & 0.05422 & 0.0354 & 0.5117 & 0.00943 \\
\hline & $(0.190)$ & $(0.484)$ & $(0.584)$ & $(0.691)$ & $(0.114)$ \\
\hline \multirow[t]{2}{*}{ Fexperience } & -0.0215 & -0.0452 & -0.00337 & $0.0071 *$ & 0.0056 \\
\hline & $(0.679)$ & $(0.476)$ & $(0.717)$ & $(0.090)$ & $(0.167)$ \\
\hline \multirow[t]{2}{*}{ Fsize } & 0.03469 & 0.01451 & 0.005436 & 0.0014 & -0.00277 \\
\hline & $(0.587)$ & $(0.385)$ & $(0.857)$ & $(0.1165)$ & $(0.758)$ \\
\hline \multirow{2}{*}{ Hhsize } & -0.0039 & -0.00754 & $-0.03459 *$ & -0.00271 & 0.0067 \\
\hline & $(0.935)$ & $(0.315)$ & $(0.064)$ & $(0.733)$ & $(0.213)$ \\
\hline \multirow[t]{2}{*}{ Access to ext } & -0.01624 & $0.0999 * *$ & 0.01017 & 0.0052 & 0.0083 \\
\hline & $(0.722)$ & $(0.021)$ & $(0.786)$ & $(0.293)$ & $(0.034)^{* *}$ \\
\hline \multirow[t]{2}{*}{ Access credit } & $0.0068 *$ & 0.0011 & 0.0088 & 0.0036 & 0.0055 \\
\hline & $(0.101)$ & $(0.528)$ & $(0.667)$ & $(0.533)$ & $(0.332)$ \\
\hline Access to & $0.0429 * *$ & 0.0025 & 0.0631 & 0.0723 & 0.0087 \\
\hline mobile phone & $(0.054)$ & $(0.277)$ & $(0.111)$ & $(0.0213)^{* *}$ & $(0.442)$ \\
\hline \multirow[t]{2}{*}{ Prain } & 0.0229 & 0.0335 & 0.01010 & 0.0669 & 0.0885 \\
\hline & $(0.1254)$ & $(0.2234)$ & $(0.2121)$ & $(0.3423)$ & $(0.080)^{* *}$ \\
\hline \multirow[t]{2}{*}{ Ptemp } & 0.00213 & 0.04332 & 0.09921 & 0.05432 & 0.06098 \\
\hline & $(0.1356)$ & $(0.5432)$ & $(0.3421)$ & $(0.1235)$ & $(0.2327)$ \\
\hline \multirow[t]{2}{*}{ Constant } & -0.02994 & $-0.01531 * *$ & -0.0752 & $-0.0496 * * *$ & -0.0884 \\
\hline & $(0.783)$ & $(0.045)$ & $(0.116)$ & $(0.002)$ & $(0.345)$ \\
\hline LR Chi 2 & $68.9874 * *$ & & & & \\
\hline Pseudo R2 & 0.2108 & & & & \\
\hline Log likelihood & -287.1667 & & & & \\
\hline
\end{tabular}

Notes: Base category: No adaptation. *,** and $* * *$ indicates $10 \%, 5 \%$ and $1 \%$ levels of statistical significance respectively. p-values are in the parenthesis 
Factors influencing the adoption of soil conservation Techniques

As shown in Table 6, the factors which significantly affect the probability of farmers using soil conservation techniques as an adaptive strategy are age (significant at $10 \%$ ), access to credit (significant at 10\%) and access to mobile phone (significant at 5\%). While age had a negative effect on the likelihood that the farmer would adapt soil conservative techniques, access to credit and access to mobile phone had a positive effect. Congruent to a priori expectation, farmers with access to credit were more likely to adapt to CCV using soil conservation techniques since they have adequate funds used to acquire the needed materials or farm inputs needed for adaptation. Recall that financial constraint was a major reason for zero adaptation by some farmers. This finding is consistent with Gbetibouo (2009) but contradicts Salau et al. (2012). The result shows the essence of supporting farmers with credit to promote the use of adaptation options, so as to reduce the negative impact of climate change and variability.

The result of age suggests that the younger farmers have a higher probability of adapting soil conservative techniques. Naturally, the younger farmers are more energetic and quick to adopt new technologies than the elderly. Older farmers are more risk-averse and also get used to a particular way of doing things and thus might have a lesser likelihood of adopting soil conservation technique in adapting to CCV. Dolisca et al. (2006) also observed that a negative effect of age on CCV adaptation but contrary to Ndambiri et al. (2013).

Consistent to apriori and Mabe et al. (2014) farmers with access to mobile phone have a high probability of adapting soil conservation techniques in response to CCV. The reason may be that farmers with access to phone easily get good farm management practices information on their phone from farmer-based organizations or can communicate with other long distant farmers.

\section{Changing crop varieties}

The factors which influence farmer's decision to change crop varieties in response to $\mathrm{CCV}$ are age, education, and access to extension services. Again, the marginal effect of age is negative and significant at $10 \%$. This suggests that younger farmers are more likely to change crop varieties as an adaptive strategy than older farmers. The implications drawn under soil conservation are applicable since the younger farmers are generally risk bearers and would want to try any new crop variety. Uddin et al. (2014) also estimated a negative effect of age on CCV adaptation.

Education has positive significant relationship with farmers' changing of crop varieties as an adaptation strategy. Formal education equips individuals with the ability and understanding of new varieties and this have effect on the adaptation decision making (Gbetibouo, 2009). A higher level of education of a farmer is likely to be associated with knowledge and information on CCV, improved technologies, and higher productivity and accordingly appropriate adaptive method would be chosen.
The positive relationship between access to extension services and the farmer's decision to adopt improved crop varieties is an indication to enhance extension service delivery and its quality to the farmers. Extension officers provide information to farmers on production practices including input usage. In recent times, extension officers direct farmers to appropriate stations to obtain the required inputs such as seed varieties. This was estimated by Tadesse et al. (2009) and also argued that farmers who have access to extension services are in the best position to receive information about adaptation methods to climate change.

\section{Irrigation}

The result in Table 6 indicates that household size (significant at $5 \%$ ) is the only variable that influences farmer's decision to adopt irrigation as adaptation strategy. Contrary to a priori expectation but consistent with Ndambiri et al. (2013), household size had negative coefficient like. As explained by Ndambiri et al. (2013), the need to earn more family income may force some households to divert part of their labour force to off-farm activities. On the flipside, Croppenstedt et al. (2003) argues that large households are more likely to adopt agricultural technology and use it more intensively since they have more labour.

\section{Changing Planting date/time}

Farmer experience, gender and access to mobile phone significantly affect farmer's decision to change planting time as adaptation strategy to CCV (Table 6). In our present study the positive relationship between farming experience (significant at 10\%) and decision to adapt to climate change is confirmed by Hassan and Nhemachena (2008) who explained that experienced farmers have better knowledge and information on changes in climatic conditions and crop management practices.

The estimate negative sign of gender means that female farmers have a higher probability of changing their planting dates than the male farmers. Generally, women are reported as more vulnerable to CCV. Therefore, it is not surprising that they would change their planting dates to respond timely to CCV. Unlike other adaptation strategies that require physical strength which naturally favour the male farmers, changing of planting dates have no relationship with physical strength. This could explain the high probability of its adoption by the female farmers.

As expected, farmers' access to mobile phone positively influences their decision to change planting date as an adaptation strategy. Implying that farmers with access to mobile phone are more likely to change planting time than those without access. With the increasing usage of internet and the influx of social media such as Facebook and WhatsApp, the role of mobile phone access, especially, smart phones cannot be underestimated. People including farmers gets to know of some climate issues through these media. Friends are able to communicate to their farmers on news of the onset of the rains (as may be reported by meteorological departments) in order to act accordingly. Hence the positive effect on 
changing planting dates, as estimated by Mabe $\boldsymbol{e t} \boldsymbol{a l}$. (2014).

\section{Mixed Cropping}

From Table 6, farmer's decision to adopt mixed cropping as an adaptation strategy is influence by access to extension and perception on reduced rainfall. Like changing planting dates, farmers engage in mixed cropping with better information from extension officers. The positive relationship between access to extension services and the farmer's decision to adopt mixed cropping. Perception on rainfall positively influence mixed cropping decisions in order to reduce impacts of $\mathrm{CCV}$. The finding of perceived reduced rainfall is expected, because farmers who perceived a decrease in rainfall may want to avoid complete crop failure by planting different crops which requires different water levels. This was also found in Lema and Majule (2009).

\section{CONCLUSIONS AND POLICY IMPLICATIONS}

The main objective of this study has been to assess the views and knowledge of smallholder farmers on $\mathrm{CCV}$, its impacts, and the various adaptation strategies and their determinants. Generally, the level of climate change awareness was high and most of them noted the effect of $\mathrm{CCV}$ on agriculture as poor crop production, increased water scarcity and increased pests and diseases. Farmers in the study area use different adaptation strategies to mitigate the negative effect of CCV and these includes mixed cropping, change crop variety, change planting time/date, adoption of soil conservation techniques, increased irrigation, migration to urban area, and increased female livestock herd. MNL was used to examine factors influencing farmers $\mathrm{CCV}$ adaptation choices. Conclusively, although there are exceptions, the factors that influenced one adaptation strategy may not necessarily influenced another. Therefore, the promotion of composite strategies needs to be carefully made, considering the socioeconomic characteristics of the farmers.

Although, most of the smallholder farmers were aware about CCV, there is still the need for farmers' education, awareness creation, provision of accessible and affordable credit and improved and modern technology to farmers as effective tools for climate change and variability adaption in the study area. The provision of extension services needs to be enhanced in order to enhance farmers' adaptation.

\section{REFERENCES}

AL-HASSAN, R. M. (2007). Regional disparities in Ghana: Policy options and public investment implications. IFPRI Discussion Papers (No. 693). https://www.africaportal.org/publications/regionaldisparities-in-ghana-policy-options-and-publicinvestment-implications/

ARKU, F. S. (2013). Local creativity for adapting to climate change among rural farmers in the semi-arid region of Ghana. International Journal of Climate Change
Strategies and Management, 5(4), 418-430. DOI: https://doi.org/10.1108/IJCCSM-08-2012-0049

ARSLAN, A., MCCARTHY, N., LIPPER, L., ASFAW, S., CATTANEO, A., and KOKWE, M. (2015). Climate Smart Agriculture? Assessing the Adaptation Implications in Zambia. Journal of Agricultural Economics, 1-29. DOI:10.1111/1477-9552.12107

BARIMAH, P. T., DOSO, J. S., and TWUMASIANKRAH, B. (2018). Impact of climate change on maize production in Ghana. A review. Journal of Agricultural Science and Applications, 3(4), 89-93. DOI: 10.14511/jasa.2014.030402

BRADSHAW, B. E. N., DOLAN, H., and SMIT, B. (2004). Farm-level adaptation to climatic vulnerability and change: Crop diversification in the Canadian Prairies. Climate Change, 67, 119-141. DOI: https://doi.org/10.1007/s10584-004-0710-z

CODJOE, S. N. A., and OWUSU, G. (2011). Climate change / variability and food systems: evidence from the Afram Plains, Ghana. Regional Environmental Change, 11, 753-765. DOI: 10.1007/s10113-011-0211-3

CROPPENSTEDT, A., DEMEKE, M., and MESCHI, M. M. (2003). Technology Adoption in the Presence of Constraints: the Case of Fertilizer Demand in Ethiopia, Review of Development Economics 7(1), 58-70. DOI: $\underline{10.1111 / 1467-9361.00175}$

DOLISCA, F., CARTER, D. R., MCDANIEL, J. M., SHANNON, D. A., and JOLLY, C. M. (2006). Factors influencing farmers' participation in forestry management programs : A case study from Haiti. Forest Ecology and Management, 236, 324-331. DOI: 10.1016/j.foreco.2006.09.017

ENETE, A. A., MADU, I. I., MOJEKWU, J. C., ONYEKURU, A. N., and EZE, F. (2011). Indigenous Agricultural Adaptation to Climate Change : Study of Imo and Enugu States in Southeast Nigeria (No. 53).

FAO. (2007). Adaptation to climate change in agriculture, forestry and fisheries: Perspective, framework and. Rome, Italy. Retrieved from www.fao.org/nr/climpag/pub/adaptation_to_climate_cha nge 2007.pdf

GANDURE, S., and ALAM, K. (2006). Climate change and smallholder farmers in Malawi: Understanding poor people's experiences in climate change adaptation. Retrieved from www.pubs.iied.org/pdfs/G00038.pdf GBETIBOUO, G. A. (2009). Understanding Farmers' Perceptions and Adaptations to Climate Change and Variability the Case of the Limpopo Basin, South Africa (No. 15-8). Washington, DC.

GREENE, W. H. (2012). Econometric analysis (Seventh ed.). England: Pearson Education Limited.

HASSAN, R., and NHEMACHENA, C. (2008). Determinants of African farmers' strategies for adapting to climate change: Multinomial choice analysis. African Journal of Agricultural and Resource Economics, 2(1), 83-104.

HAUSMAN, J. and MCFADEN, J. (1984). Specification Tests for the Multinomial Logit Model. Econometrica, 52(5). DOI: 10.2307/1910997

JONES, P. G. and THORNTON, P. K. (2003). The potential impacts of climate change on maize production in Africa and Latin America in 2055. Global 
Environmental Change, 13, 51-59. DOI: 10.1016/S09593780(02)00090-0

KURUKULASURIYA, P. and ROSENTHAL, S. (2003). Climate Change and Agriculture: A review of impacts and adaptations (Climate Change Series No. 91). Washington, D.C.

LAUBE, W., SCHRAVEN, B. and AWO, M. (2012). Smallholder adaptation to climate change : dynamics and limits in Northern Ghana. Climatic Change, 111, 753774. DOI: $10.1007 / \mathrm{s} 10584-011-0199-1$

LEMA, M. A. and MAJULE, A. E. (2009). Impacts of climate change, variability and adaptation strategies on agriculture in semiarid areas of Tanzania: The case of Manyoni District in Singida Region, Tanzania. African Journal of Environmental Science and Technology, 3(8), 206-218. DOI: 10.5897/AJEST09.099

LIMANTOL, A. M., KEITH, B. E., AZABRE, B. A. and LENNARTZ, B. (2016). Farmers' perception and adaptation practice to climate variability and change: a case study of the Vea catchment in Ghana. SpringerPlus. Springer International Publishing. DOI: 10.1186/s40064016-2433-9

LLOYD, S. J., KOVATS, R. S. and CHALABI, Z. (2011). Climate Change, Crop Yields, and Undernutrition: Development of a Model to Quantify the Impact of Climate Scenarios on Child Undernutrition. Environmental Health Perspectives, 119(12), 1817-1824. doi: $10.1289 /$ ehp.1003311

MABE, F. N., SIENSO, G. and DONKOH, S. (2014). Determinants of Choice of Climate Change Adaptation Strategies in Northern Ghana. Research in Applied Economics, 6(4), 75-94. DOI: 10.5296/rae.v6i4.6121

MCFADDEN, D. (1973). Conditional logit analysis of qualitative choice behaviour (pp. 105-142).

MERTZ, O., MBOW, C., REENBERG, A. and DIOUF, A. (2009). Farmers' Perceptions of Climate Change and Agricultural Adaptation Strategies in Rural Sahel. Environmental Management, 43, 804-816. DOI: $\underline{10.1007 / \mathrm{s} 00267-008-9197-0}$

NDAMBIRI, H. K., RITHO, C. N. and MBOGOH, S. G. (2013). An Evaluation of Farmers ' Perceptions of and Adaptation To the Effects of Climate Change in Kenya. International Journal of Food and Agricultural Economics, 1(1), 75-96. Retrieved from http://foodandagriculturejournal.com/75.pdf

NHEMACHENA, C. and HASSAN, R. (2007). Microlevel Analysis of Farmers' Adaptations to Climate Change in Southern Africa. Washington, DC.

NYASIMI, M., AMWATA, D., HOVE, L., KINYANGI, J. and WAMUKOYA, G. (2014). Evidence of Impact: Climate-Smart Agriculture in Africa. Wageningen, Netherlands: CGIAR Research Program on Climate Change, Agriculture and Food Security (CCAFS) and the Technical Centre for Agricultural and Rural Cooperation (CTA).

NZEADIBE, T. C., EGBULE, C. L., CHUKWUONE, N. A. and AGU, V.C. (2011). Climate change awareness and resilient adaptation: indigenous drivers of regional sti policy in Niger Delta. African Technology Policy Studies Network, 1-10.

PHILLIPO, F., BUSHESHA, M. and MVENA, Z. S. K. (2015). Adaptation strategies to climate variability and change and its limitations to smallholder farmers. A literature search. Asian Journal of Agriculture and Rural Development, 5(3), 77-87.

QUAYE, W. (2008). Food security situation in northern Ghana, coping strategies and related constraints. African Journal of Agricultural Research, 3(5), 334-342.

ROWELL, M. J. (1995). Colorimetric method for CO2 measurement in soils. Soil Biology and. Biochemistry, 27(3), 373-375. DOI: https://doi.org/10.1016/00380717(94)00218-P

SALAU, E. S., ONUK, E. G. and IBRAHIM, A. (2012). Knowledge, Perception and Adaptation Strategies to Climate Change among Farmers in Southern Agricultural Zone of. Journal of Agricultural Extension, 16(2), 199211. DOI: http://dx.doi.org/10.4314/jae.v16i2.15

SERDECZNY, O., ADAMS, S., BAARSCH, F., COUMOU, D. and REINHARDT, J. (2016). Climate change impacts in Sub-Saharan Africa: from physical changes to their social repercussions. Regional Environmental Change. DOI: 10.1007/s10113-015-0910$\underline{2}$

STANTURF, J. A., WARREN, M. L., CHARNLEY, S., POLASKY, S. C., GOODRICK, S. L., ARMAH, F. and NYAKO, Y. A. (2011). Ghana climate change vulnerability and adaptation assessment. Accra, Ghana. TADESSE, T., HASSAN, R. M., RINGLER, C., ALEMU, T., and YESUF, M. (2009). Determinants of farmers' choice of adaptation methods to climate change in the Nile Basin of Ethiopia. Global Environmental Change, 19, 248-255. DOI: 10.1016/j.gloenvcha.2009.01.002

TSE, Y. K. (1987). Model Logit Test for the Multinomial. Journal of Business and Economic Statistics, 5(2), 283 286.

TURNER, A. N. C., LI, C. F., XIONG, C. Y., KADAMBOT, B. and SIDDIQUE, H. M. (2011). Climate change and agricultural ecosystem management in dry areas. Crop and Pasture Science. DOI: 10.1071/FP11031 UDDIN, M. N., BOKELMANN, W. and ENTSMINGER, J. S. (2014). Factors Affecting Farmers' Adaptation Strategies to Environmental Degradation and Climate Change Effects: A Farm Level Study in Bangladesh. Climate, 2(24), 223-241. doi:10.3390/cli2040223 